Conservation and Society 8(1): 84-97, 2010

$\underline{\text { Article }}$

\title{
Traditional Laws Pertaining to Sea Turtle Consumption in Polynesia (Including the Polynesian Outliers)
}

\author{
Regina Woodrom Rudrud
}

University of Hawai'i at Mānoa, Honolulu, HI, USA

E-mail: ReginaL@hawaii.edu

\begin{abstract}
Throughout the Pacific regions of Micronesia, Melanesia and Polynesia, sea turtles are recognised as culturally significant species. The specifics of human-sea turtle interactions in these regions, however, are not well known, in part because ethnographic and historic reports documenting these interactions are scattered, requiring extensive archival research. Ethnographic and environmental data collected over a ten-year period are analysed to assess patterns of human-sea turtle interactions prior to (and sometimes beyond) Western contact. From the ethnographic data for Polynesia, a region-wide pattern emerges where sea turtle consumption was restricted to special ceremonies when the elites such as chiefs and priests but no one else ate turtle. Only in two countries did this pattern differ. Environmental data does little to elucidate explanations for this region-wide treatment of sea turtles as restricted food sources, as there is no correlation between environmental variability and the presence or absence of these restrictions. Instead the results of this research suggest such practices may have been part of an ancestral Polynesian society, developing well before human settlement into this region of the Pacific.
\end{abstract}

Keywords: sea turtle, Oceania, Pacific, Polynesia, taboo, kapu, tapu, traditional take, cultural take, cultural value, traditional ecological knowledge, traditional conservation measures

DOI: $10.4103 / 0972-4923.62669$

\section{INTRODUCTION}

Revered as sacred animals, desired as prestigious forms of ceremonial food and iconised in symbolism in the Pacific Islands ${ }^{1}$, the sea turtles' cultural valuation in Pacific society is far above that of other marine animals (Woodrom Rudrud et al. 2007). In the past, these practices often manifested through the development of various consumptive taboos (tapus, kapus) or traditional laws that demonstrated a 'cultural valuation' that elevated sea turtles above other food sources (Woodrom Luna 2003). These practices may have begun or been promoted for any number of reasons, but the result was often consistent with modern conservation practices regarding turtle species as well as the further elevation of the sea turtles' significance and value in the culture involved.

The study of sea turtles as restricted food sources examines the cultural constructions and physiological implications of diet across time, space, society, and culture. 'An integrated biocultural perspective comprehends that foods have both tangible (physical) and intangible (meaning-centered, symbolic) realities, and that a particular cuisine is best understood in the specific cultural-environmental-political matrix in which it has developed' (Etkin 2008: 1). Foods speak to both tradition and continuity and to modernity and change. They foster identities at the same time that they create and enforce boundariesamong social classes, genders, ages, and so on (Etkin 2008).

Presently, despite national and international protection as endangered species, sea turtles remain prestigious, desirable, and ceremonially important sources of food and other commodities for Pacific populations; the relatively new and international science of sea turtle conservation does not counter or diminish traditional valuation and uses of sea turtles (Woodrom Rudrud et al. 2007). Sea turtles are increasingly symbolic of a traditional Pacific Islander culture that may be permanently altered as endangered species and their habitats are sheltered.

This paper documents human-turtle relationships in the cultural area of the Pacific commonly referred to as Polynesia

Copyright: (C) Regina Woodrom Rudrud 2010. This is an open access article distributed under the terms of the Creative Commons Attribution License, which permits unrestricted use and distribution of the article, provided the original work is cited. 
(including the Polynesian Outliers and excluding New Zealand) and is part of a larger project exploring alternative explanations for the widespread use and reverence of turtles, not only in Polynesia, but throughout the Pacific Islands. Two sources of quite different published data are utilised. Ethnographic studies and historical accounts supply information on the rich social context of turtle consumption as well as the traditional laws and management practices that regulated that consumption. Environmental data is utilised to give an approximation of what living in Polynesia may have been like, at the time these traditional laws were in place. An effort is made not only to outline regional patterns but also to examine if these two types of data can be correlated as previously proposed (Johannes 2002; Allen 2007), for example, do certain types of environments lead to more or less the same consumptive restrictions on sea turtles as food? Finally, this analysis will assist ongoing efforts to conserve and restore Pacific turtle populations and inform those involved in determining the outcome of requests by Pacific Island nations for a 'cultural' or 'traditional' take of sea turtles (Chaloupka \& Balazs 2007; Kinan \& Drexel 2005; McCoy 1997).

\section{METHODS}

\section{Ethnographic studies and historical accounts}

In order to collect ethnographic and historical data on traditional laws and management measures regarding sea turtle consumption, I conducted an extensive literature review over a ten-year period. As much as possible, primary sources were studied. Because use that was purely consumptive in nature, such as hunting techniques and amount of turtles taken, has been extensively discussed and analysed in sea turtle conservation literature such aspects were not included.

The data acquired from these sources was reported by the various authors using a wide variety of spatial scales - some presenting their data as representing cultural traits for entire regions, some as traits for an island group or nation, some for only one island or atoll and some for just an individual village or province on a particular island. Therefore, I collated the data to represent the island groups that currently make up the geographic area of Polynesia (Figure 1): The Cook Islands, French Polynesia, The Hawaiian Islands, Niue, The Pitcairn Islands, Rapa Nui, Samoa (American and Western), Tokelau, Tonga, Tuvalu and Wallis and Futuna.

\section{Environmental studies}

To collect the necessary data needed to provide a picture of the environments the creators and maintainers of these traditional laws were living on; I conducted an extensive literature review. I began with the United Nations Environment Programme (UNEP) database of islands and small-island states (UNEP 1998-2006). The database gives information on island type (atoll, high volcanic, low coral, and so forth), maximum elevation and land area, and types of ecosystems present as well as special indicators such as isolation index (the sum of the square roots of the distances to: the nearest equivalent or larger island, group or archipelago, and continent), natural catastrophic threat indicator (hurricanes, volcanic eruptions, earthquakes, droughts, fires, etc.), number of ecosystems (terrestrial and marine), and species richness (terrestrial and marine). This information was input into a data matrix with each row representing a different location and each column representing a different type of information.

Because the island data in the UNEP database was at times incomplete, I supplemented this information by conducting a thorough review of all documents in the Pacific Environment Information Network (PEIN) Country Profiles Directory on the webpage of the Secretariat of the Pacific Regional Environmental Programme (SPREP) (PEIN 2010). Information obtained from the SPREP review included land area, sea area, highest elevation, types of ecosystems present, number and types of documented species, biodiversity and exposure to natural disasters. In addition, the Environmental Vulnerability Index - Country Profiles (EVI) contained several special indices that were also added to the data matrix (EVI 2010). These indicators include:

- Lowlands; percent of land area less than or equal to $10 \mathrm{~m}$ or less above mean sea level (msl)

- Land area; the richness of habitat types and diversity, availability of refuges if damage is sustained or for protection, and species and habitat redundancy

- Relief; highest point subtracted from lowest point

- High winds; likelihood of damage from frequent and severe wind

- Dry periods; drought, dry spells, stress on surface water resources

- Wet periods; vulnerability to floods, cyclones, wet periods, stress on land surfaces and ecosystems subject to flooding and disturbance

- Hot periods; heat waves, desertification, water resources, temperature stress, bleaching

- Cold periods; cold snaps, unusual frosts, effects on water resources, temperature stress, pollution attenuation rates, reproductive success

- Sea temperatures; fluctuations in productivity, fisheries, currents, eddies, ENSO, cyclones and storms, blooms and coral bleaching

- Volcanoes; eruptions, landslides, geysers, gas, fires, ash, dust, marine kills, biodiversity of habitat \& species, potential for repeated and long term habitat disturbance

- Earthquakes; habitat disturbance through movements of land, water and slides

- Tsunamis; loss of shorelines, coastal ecosystems and resources, and loss of species due to catastrophic run up of seawater onto coastal lands

- Slides; habitat disturbance and persistence of ecosystems and species from catastrophic shifts in the land surface

All of this additional information was added to the data matrix. Furthermore, information from both sets of environmental data (UNEP and SPREP) were extrapolated 


\section{6 / Regina Woodrom Rudrud}

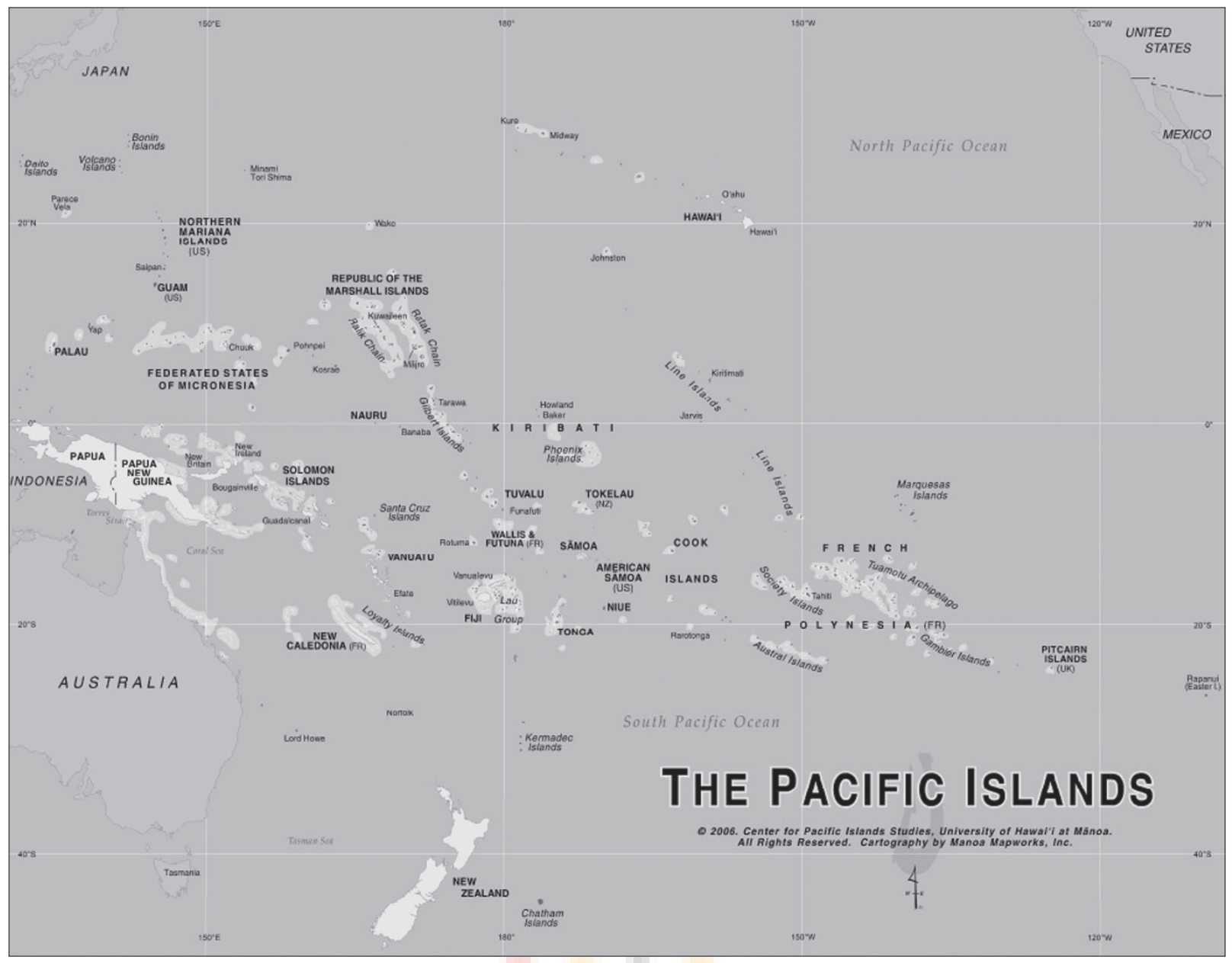

Figure 1

Map of the Pacific

to determine the value for any missing special indicators as follows: types of ecosystems present was used to determine number of terrestrial and marine habitats, number and types of documented species were used to determine a number for described terrestrial and marine species as well as species richness, and the EVI special indices relating to vulnerability from disasters (land area, high winds, dry periods, wet periods, hot periods, cold periods, sea temperatures, volcanoes, earthquakes, tsunamis, slides) were combined into one column under Total Vulnerability.

\section{RESULTS}

\section{Environmental Characteristics}

The geographic and environmental characteristics of Polynesian countries that have reports of traditional sea turtle consumption laws are listed in Table 1, which is used to compare these indicators to determine if any correlate with consumption restricted to elites. Lowlands is the percent of land area less than or equal to $10 \mathrm{~m}$ above msl (EVI 2010). Isolation Index is the sum of the square roots of the distances to the nearest equivalent or larger island, group or archipelago, and continent (UNEP 1998-2006). Total Vulnerability is environmental vulnerability due to natural disasters including impact on habitats, ecosystems and species (higher numbers equal greater vulnerability) (EVI 2010). Threat Indicator is the number of different types of catastrophic events reported in the region (UNEP 1998-2006). Terrestrial Ecosystems is a count of the number of described terrestrial ecosystem or biome types. Marine Ecosystems is a count of the number of described marine ecosystem or biome types. Biodiversity Score is a measure of total biodiversity in an area (EVI 2010). Described Terrestrial Species is the total number of different terrestrial species reported in the region. Described Marine Species is the total number of different marine species reported in the region. Estimated Number of Described Species is the sum of terrestrial and marine species, though in some references was given as an independent number and in those cases is not the sum of the two previous columns (UNEP 1998-2006; SPREP 2010). Land Area Indicator captures the richness of habitat types and diversity, availability of refuges if damage is sustained or for protection, and species and habitat redundancy $(\mathrm{EVI})$. 


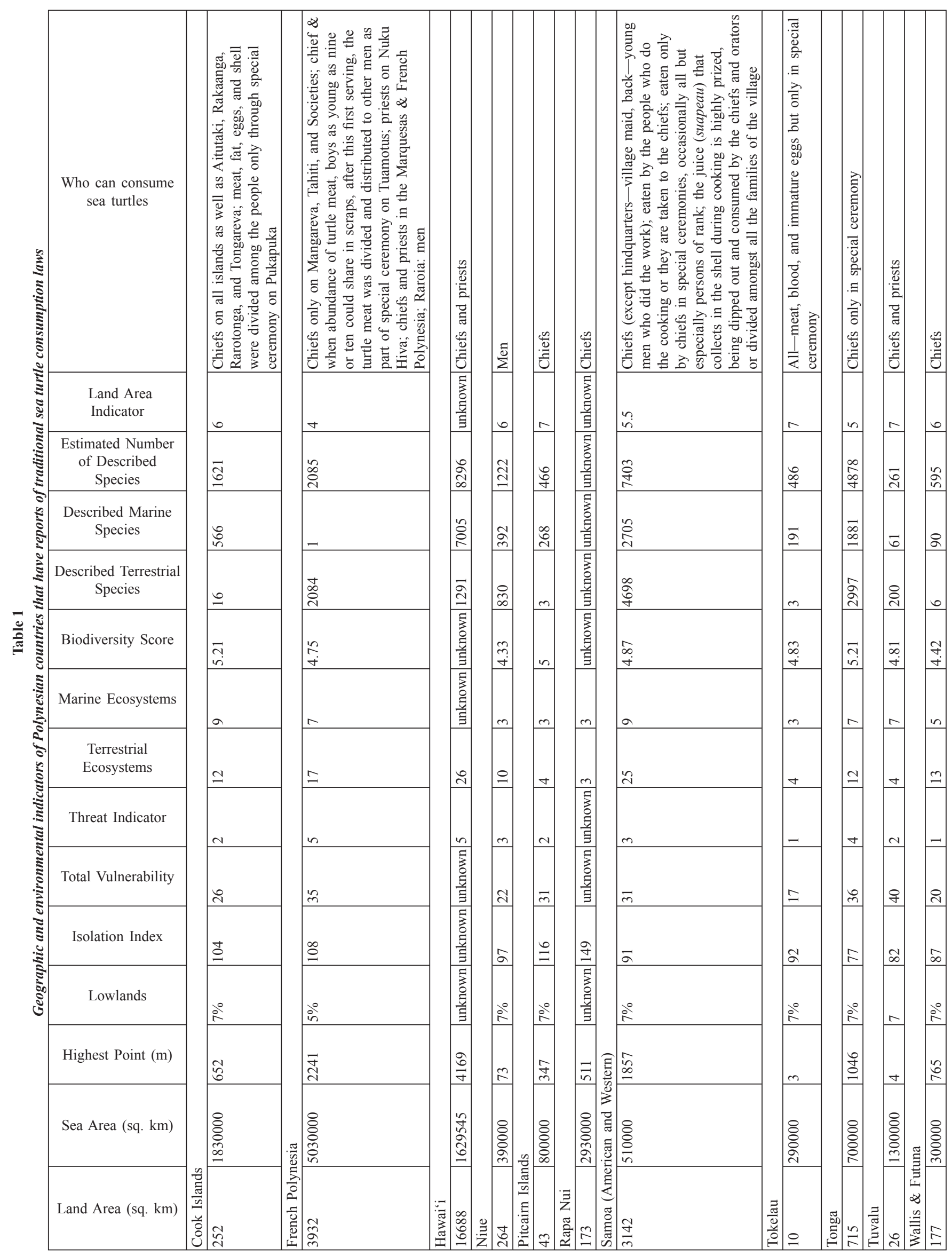




\section{8 / Regina Woodrom Rudrud}

The geographic and environmental characteristics of individual Polynesian Islands, including Outliers, which have reports of traditional sea turtle consumption laws, are listed in Table 2, which is used to compare these indicators to determine if any correlate with consumption restricted to elites. Isolation Index is the sum of the square roots of the distances to: the nearest equivalent or larger island, group or archipelago, and continent. Threat Indicator is the number of different types of catastrophic events reported (UNEP 1998-2006). Terrestrial Ecosystems is a count of the number of described terrestrial ecosystem or biome types. Marine Ecosystems is a count of the number of described terrestrial ecosystem or biome types. Terrestrial Species Richness: [0 $=<24$ plants and/or $<8$ birds; $1=25-224$ plants \&/or 9-23 birds; $2=225-624$ plants \&/ or 24-39 birds; $3=625-1224$ plants \&/or 40-55 birds; $4=$ 1225-2024 plants \&/or 56-71 birds; $5=>2025$ plants \&/or $>72$ birds] (UNEP 1998-2006). Marine Species Richness follows the same scale as that used for terrestrial plants, based on the few categories of organisms such as fish, corals or molluscs for which species data are available] (UNEP 1998-2006; SPREP 2010)

\section{Polynesia}

Two authors discuss consumption of sea turtles in terms of the entire region of Polynesia and report that sea turtles were owned by the chiefs and priests and it was dangerous for a nonchief to eat one (Handy 1927; Oliver 2002). Further reports detail the specifics for the various island groups that constitute the region, which have traditional laws regarding sea turtle consumption. These reports are presented below along with general information regarding the geology and environment of these groups and the sea turtle species that have been reported within them.

\section{The Cook Islands}

The Cook Islands consist of low coral atolls in the north and volcanic, hilly islands in the south. Six of the islands have a surface area less than $100 \mathrm{sq}$. $\mathrm{km}$ and nine have a surface area less than 10 sq. $\mathrm{km}$. The country covers 252 sq. $\mathrm{km}$ of land and a sea area of 1,830,000 sq. km. The highest point, which lies on the island of Rarotonga, is $652 \mathrm{~m}$ above $\mathrm{msl}$ (UNEP 1998-2006). The climate is tropical with an average temperature of $26^{\circ} \mathrm{C}$ and average rainfall of $2,076 \mathrm{~mm}$ per year (UNEP 1998-2006; MRCI undated). Sources of fresh water include springs and streams, rainwater and well water, freshwater marshes and swamps (Rarotonga, Mangaia, Atiu, Mitiaro and Mauke), permanent freshwater lakes (Mangaia, Atiu, Mitiaro), and mountain streams on Rarotonga (SOPAC 2008; UNEP-WCMC undated). The terrestrial ecosystems include montane forest, montane-slope forest, Fagraea-Fitchia ridge forest, Metrosideros cloud forest, lowland limestone rainforest on several of the high islands, atoll forest and beach forest on atolls and reef islets, coconuts and scrub on coral islets, scrub and grassland formations, Dicranopteria fernlands, and limestone caves. All of the Cook Islands have extensive coral formations, generally as fringing and lagoon reef (UNEP-WCMC undated). Marine ecosystems include windward and leeward atoll reef, closed and open lagoons, reef flat, patch reef, fringing reef, barrier reef, outer reef slope, and tidal salt marsh on Rarotonga (UNEP 1998-2006; MRCI undated; CIBD 2007).

Three species of sea turtles have been reported in the Cook Islands-green (Chelonia mydas), hawksbill (Eretmochelys imbricata) and loggerhead (Caretta caretta). Researchers and community members have documented nesting by green turtles on Rakahanga Atoll and on Turtle and Mangaia Islands. Nesting by both green turtles and hawksbill turtles has been reported on Manihiki, Pukapuka, Suwarrow, Tongareva and Palmerston Atolls as well as on Atiu, Mauke, Nassau and Rarotonga Islands (CIBD 2007; UNEP 1998-2006; MRCI undated; Pulea 1997). Additional reports on nesting in the islands do not list the species but do note that nesting occurs. These islands include Aitutaki and Manuae Atolls, and Takutea Island (CIBD 2007; UNEP 1998-2006; MRCI undated).

Reports of traditional regulation of sea turtle consumption in the region vary. Early reports discuss purely chiefly consumption throughout the county (Gill 1885 cited in Crocombe 1961; Williamson 1933). Additional sources writing about Aitutaki, Rakahanga, and Tongareva Atolls as well as the island of Rarotonga support those reports with priests additionally able to eat turtle on Tongareva and Rarotonga (Williams 1837; Gill 1885; Pakoti 1895; Ariki-tara-are 1919; Smith 1899; Smith 1903; Large 1903; Hiroa 1932). At Pukapuka Atoll, however, reports indicate consumption by all people but only through special ceremony (Beaglehole \& Beaglehole 1938; Parsons 1962).

\section{French Polynesia}

French Polynesia includes five archipelagos (4 volcanic, 1 coral). The Islands vary in size with surface areas ranging from between 1,000 and 10,000 sq. km (one), less than 1,000 sq. $\mathrm{km}$ (five), less than 100 sq. km (21), less than 10 sq. km (12) to less than 1 sq. $\mathrm{km}$ (one). The country covers 3,932 sq. $\mathrm{km}$ of land and a sea area of 5,030,000 sq. km. The highest point, which lies on the island of Tahiti, is $2,241 \mathrm{~m}$ above msl. The climate is tropical with an average temperature of $26^{\circ} \mathrm{C}$ and average rainfall of 2,813 $\mathrm{mm}$ per year (UNEP 1998-2006). Water sources such as lakes or rivers are absent, leaving the only source of fresh water as catchments of rainwater (UNEPWCMC undated).

Interior rainforests characterise the higher islands, while the atolls have ground covers such as Sesuvium and salt-hardy trees like coconut palms. Terrestrial ecosystems in French Polynesia include lowland and montane rainforest, limestone forest, grassland, fernland on upper slopes, cloud forest with tree ferns and epiphytes, forest remnants in ravines, and casuarina and coconuts on reef islets in the Austral Islands. Atoll forest and scrub and reed grassland cover most areas in the Gambier Islands. Terrestrial ecosystems in the Marquesas 


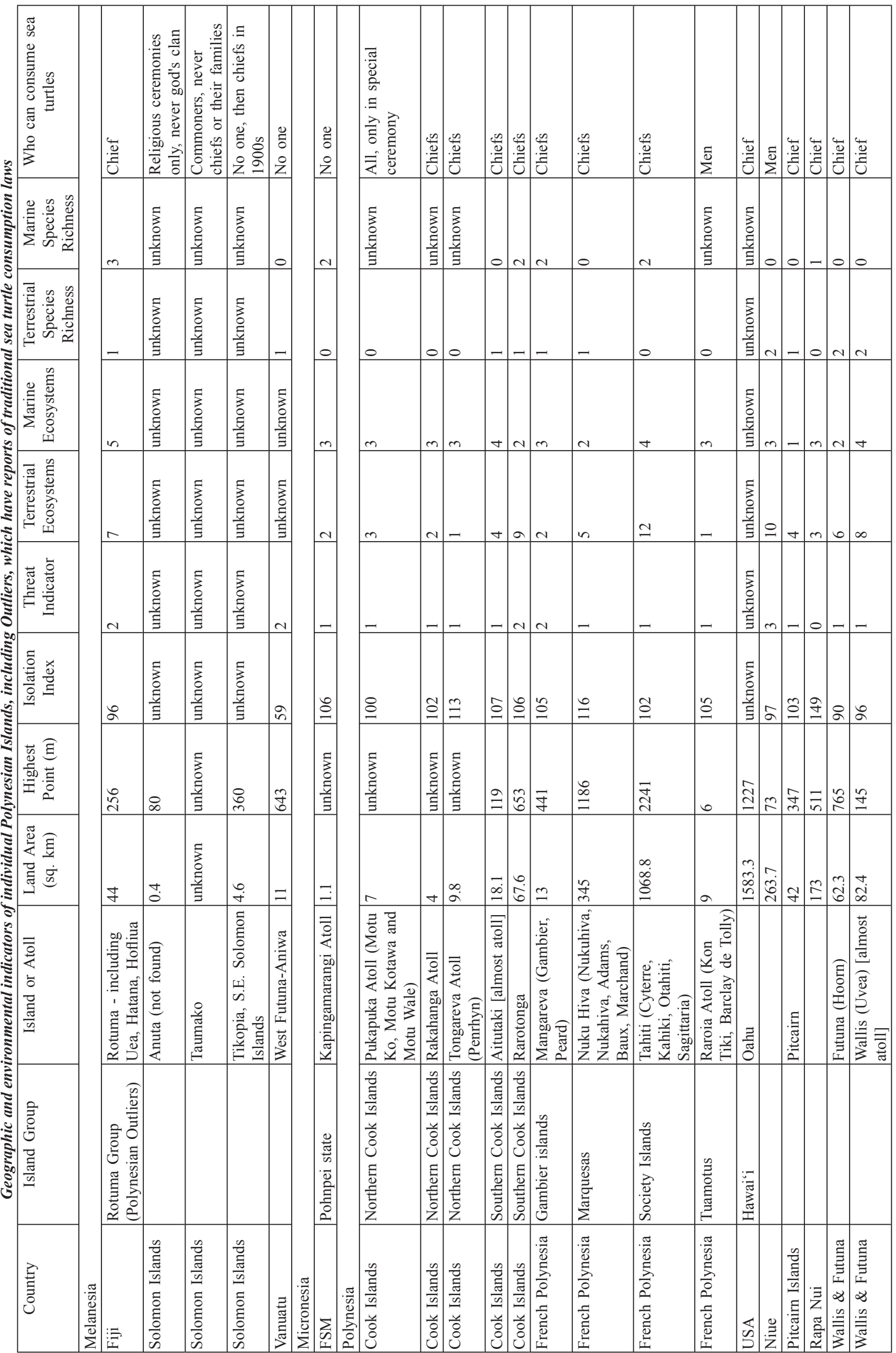




\section{0 / Regina Woodrom Rudrud}

include montane rainforest, rainforest and cloud forest above $1,000 \mathrm{~m}$, tree ferns, intermediate rainforest on plateaus, Pisonia forest, grasslands and dwarf scrub. Tropical and subtropical moist broadleaf forests, which occur in three general forms, dominate the Society Islands: lowland rainforest, montane rainforest, and cloud forest. Additional ecosystems include bamboo forest, swamp forest as well as atoll scrub, grassland and fernland on upper slopes, and freshwater habitats including streams, rivers and lakes (UNEP 1998-2006; Fosberg 1992 cited in WWF 2001). In the Tuamotus mixed broadleaf forests are the dominant vegetation throughout the region. Less dominant habitats in the Tuamotus include atoll forest and scrub, limestone forest, dry scrub, remnant beach scrub and a narrow swamp inside the lagoon shore on Niau (WWF 2001).

Much of French Polynesia contains barrier reef and lagoons with rich coral fauna. The Tuamotus feature windward and leeward atolls reef, fringing reef, patch reef with relatively rich coral fauna, closed lagoons with low coral diversity but high abundance of Porites mordax and Acropora formosa and high density of Tridacna maxima, open lagoons, and large seagrass beds. Windward and leeward atoll reef, fringing reef, patch reef, closed and open lagoons also characterise the Society Islands marine environment, which also contains barrier reef and coral communities on submarine slopes. The Marquesas, Gambiers, and Austral islands contain very few corals, have fringing reef in some bays, relative poor barrier reef, and lagoons with poor lagoon fauna - though the Gambiers have a lagoon with rich coral fauna on pinnacles, and there is a coralline algal bank on Motu One in the Marquesas (WWF 2001).

While only one species of sea turtles has been reported as nesting in French Polynesia (green at Manuae where 300-400 nesters are estimated), several other areas are known for turtle-nesting though reports do not indicate the species. These include Maupihaa, Motu One, Paraoa, Kauehi, Napuka, Pukapuka, and Apaataki (Craig et al. 2004; UNEP 1998-2006).

Throughout French Polynesia sea turtle consumption was restricted to the elite — chief and priests (Emory 1947; Balazs et al. 1995). One report from the Tuamotus goes so far as to state, 'all the world knows that the turtle is royal food in Polynesia' (Audran 1918: 27). As could be expected in such a large region slight differences in traditional law within the country have been reported. On Mangareva in the Gambier Islands only chiefs were allowed to eat turtle, while in the Marquesas all chiefs and priests could (Hiroa [Buck] 1938a; Handy 1923). In the Society Islands only the chiefs could partake of sea turtle and this is substantiated by additional reports from the island of Tahiti (Wilson 1799; y Varela 1913 cited in Ferdon 1981; Ellis 1831; Williams 1837; Montgomery 1841; Handy 1927). In the Tuamotus various authors suggest that though chiefs ate first, after they were sated all men present could partake - though only through special ceremony (Montiton 1874 cited in Emory 1947; Hiroa [Buck] 1938b; Danielsson 1954; Emory 1975). Montiton reports when turtle was 'abundant... boys as young as nine or ten years... were sometimes allowed... to share in the scraps' (Montiton 1874: 370 cited in Emory 1947: 87; Montiton 1874: 378-379 cited in Rolett 1986: 85).

\section{The Hawaiian Islands}

The Hawaiian archipelago covers $16,688 \mathrm{sq} . \mathrm{km}$ of land and a sea area of 1,629,545 sq. km. The highest point, which lies on the island of Hawai' $i$, is approximately 4,169 $\mathrm{m}$ above msl (UNEP 1998-2006). The climate is tropical with an average temperature of $26^{\circ} \mathrm{C}$ and average rainfall of $2,076 \mathrm{~mm}$ per year (TGOF 2009).

The terrestrial ecosystems of the Hawaiian Islands include savannah and dry grassland, dryland forest or scrub, open forests, mixed mesophytic forest (woodland or scrub), pen Acacia forests, lowland rainforest, montane rainforest, upper montane rain or cloud forest, subalpine forest and scrub, mountain parkland and savannah, sparse alpine scrub, windward and leeward beach dune and rock-substrates, lowand mid-elevation bogs, montane bogs, lava tubes, fresh water lakes, streams, coastal brackish and marine ponds, and cliffs. All of the Hawaiian Islands have rich marine ecosystems (Stone \& Scott 1985).

Five species of sea turtles are found in Hawaiian waters, the leatherback (Dermochelys corniacea), green, hawksbill, loggerhead, and olive ridley (Lepidochelys olivacia) (Gulko 1998, NMFS 1998). Approximately 10-15 hawksbill nests are laid per year in the state of Hawai' $i$ (Beaches on Hawai' $i$ Island and Mau'i, Moloka'i, and O'ahu Islands). Ninety percent of the nesting occurs on the $\mathrm{Ka}^{\text {' }} \mathrm{u}$ coast of Hawai' $\mathrm{i}$ Island (PWF undated). There is also scattered green, hawksbill and olive ridley nesting reported on Kaua' $\mathrm{i}$ and $\mathrm{O}^{\text {‘ }}$ ahu (pers. com. George Balazs NOAA 2008; per. com. Don Heacock DLNR 2009) and approximately 600 female green turtles nest each year at French Frigate Shoals in the Northwest Hawaiian Islands (Balazs 2010).

Traditional regulations regarding sea turtle consumption in Hawai' $i$ have been reported at several different time periods. The earliest report that could be found by this author was written by Captain James Cook in 1821 who stated that turtle was forbidden to women (Cook 1821b). Subsequent reports also discuss turtle as food consumed only by men (Ellis 1827; Hutton 1874; Bryan 1938; Malo 1951; Handy \& Pukui 1953; Linnekin 1990). However King Kalakaua's book, The Legends and Myths of Hawaii, published in 1888 contained a foreword by Dagget, an American minister working in Hawai'i, who writes, 'squid, turtle, and two or three species of birds could be eaten only by the priests and tabu royalty' (32). Consumption restricted to priests and chiefs was also reported in later accounts (Jordan \& Evermann 1902; Markrich 1983 both cited in Johannes 1986; Handy 1927; Malo 1951; Handy \& Handy 1972; Meller 1985). Johannes (1986) interpreted the traditional laws as restricted to the green turtle, writing, in his introduction to King Kalakaua's The Legends and Myths of Hawaii, published in 1888, that 'eating green turtle was forbidden to all but priests and chiefs' (30-31).

In contrast to both of the above assertions (eaten by all men, or only by elites), Johannes (1986) quotes a contemporary Hawaiian scholar, Piianaia, as believing that turtle was not limited to the upper classes and was common food, for both 
sexes. 'He [Piianai] states that Daggett was an 'outsider' writing about customs that had disappeared two generations earlier' (Markrich 1983 cited in Johannes 1986: 30-31). This author notes that Piianaia is in effect stating that in the past turtle consumption was restricted to the elite.

\section{Niue}

Niue is a raised coral island consisting of a raised coral platform with terraced coastal cliffs. It is one of the largest coral islands in the world (UNEP 1998-2006; PBIF undated). The island covers 264 sq. $\mathrm{km}$ of land and a sea area of 390,000 sq. km. The highest point is $73 \mathrm{~m}$ above sea level (UNEP 1998-2006). Niue's climate is tropical with an average temperature of $28^{\circ} \mathrm{C}$ and average rainfall of 2,180 mm per year (UNEP 1998-2006, SOPAC 2008). The island has a thin generally fertile but shallow soil partly of volcanic ash origin with high natural radioactivity. The island is composed of pure limestone of three types - reef rock, beach conglomerate, and cemented or loose coral sand (Lane 1994 cited in Government of Niue 2001). A permanent fresh water table is located approximately $60 \mathrm{~m}$ below the rim of the central plateau and is the main source of freshwater (Nemaia 2004).

The principal terrestrial ecosystems on Niue are lowland rainforest on raised coral substrate (limestone forest), coastal forest on terraces, secondary forest and fern-scrub barrens (UNEP-WCMC undated). Several less common types of habitat areas are also recognised including littoral shrub, littoral forest, mature forest, limestone rainforest and caves. The marine ecosystems include fringing reef and terraced coralline algal pools but no fringing coral reef(Nemaia 2004; WWF 2001).

Two species of sea turtles have been reported for Niue- the green and the hawksbill (Government of Niue 2001).

Traditional law confined sea turtle consumption to men (Loeb 1926).

\section{The Pitcairn Islands}

The Pitcairn Islands consist of four islands, one of which is less than 100 sq. km, one less than 10 sq. km, and two that are less than $1 \mathrm{sq}$. km. They encompass a land area of approximately 43 sq. $\mathrm{km}$ and a sea area of approximately 800,000 . The highest point, which is on Pitcairn Island, is $347 \mathrm{~m}$ above $\mathrm{msl}$. The climate is subtropical with an average temperature of $23^{\circ} \mathrm{C}$ and average rainfall of $1,250 \mathrm{~mm}$ per year. There is little to no surface water (UNEP 1998-2006).

Many terrestrial ecosystems have been described for the Pitcairn Islands: atoll forest, lowland and montane rainforest, scrub forest, littoral and rocky coast, limestone plateau, strand vegetation, beachridge/backbarrier on sand, Miro woodland, limestone glade woodland, limestone cliffs, cliff top/margin, pinnacled limestone, Timonius scrub, dense limestone scrub, and grasslands and fern slopes in rocky littoral areas. Marine ecosystems include raised patch reef communities, windward and leeward atoll reef with extensive algae and coralline algae in shallows, coral on deep reef, productive lagoon with poor circulation but fair coral cover on pinnacles, and fringing reef (UNEP 1998-2006).

One species of sea turtle has been reported in the Pitcairn Islands - the green, which is reported to nest on Henderson Island (UNEP 1998-2006). Turtle consumption patterns for the Pitcairn Islands are unknown. However, archaeological remains suggest Polynesians inhabited Pitcairn Island about 600 years ago, probably arriving from Mangareva some $490 \mathrm{~km}$ away in the Gilbert Group of French Polynesia (Sharp 1963). It can therefore be inferred that traditional laws concerning sea turtle consumption would be the same as on Mangareva with only chiefs allowed to eat turtle.

\section{Rapa Nui}

Rapa Nui consists of four islands; one less than 100 sq. km, one less than 10 sq. $\mathrm{km}$, and two less than $1 \mathrm{sq}$. km. The country covers 173 sq. km of land and a sea area of 2,930,000 sq. km. The highest point, located on Rapa Nui Island, is $511 \mathrm{~m}$ above msl. The climate is subtropical with an average temperature of $23^{\circ} \mathrm{C}$ and average rainfall of $1,250 \mathrm{~mm}$ per year (UNEP 1998-2006). There is little surface water. During the time frame considered in this report, the island was forested with a range of trees, shrubs, ferns, and grassland within the crater lakes of Rano Raraku and Rano Kau (McAlester undated).

This author was unable to locate reports of sea turtle species and behaviours for Rapa Nui.

Traditional laws regulating consumption of sea turtles stated that, 'the meat of the turtle was set aside for the king...' (Barthel 1923: 142).

\section{Samoa (American and Western)}

Samoa consists of seven high volcanic islands with rugged peaks and limited coastal plains, two coral atolls (Rose and Swains), and several smaller islands and uninhabited islets (PBIF undated). There are 14 main islands: two less than 10,000 sq. km; one less than 1,000 sq. km, one less than 100 sq. km, six less than 10 sq. km, three less than 1 sq. km, and one island for which this author could find no data. The country covers 3,100 sq. $\mathrm{km}$ of land and a sea area of 510,000 sq. km. The highest point, on the island of Savai $i$, is approximately $1,857 \mathrm{~m}$ above msl. The climate is tropical with an average temperature of $27^{\circ} \mathrm{C}$ and average rainfall of 2,000 mm per year (UNEP 1998-2006). Surface water and groundwater exist across almost the entire country, although they are quite noticeably different in their distribution. The exception is Apolima where natural fresh water resources are limited (UNEP-WCMC undated).

The principal terrestrial ecosystems in Samoa are tropical and subtropical moist broadleaf forests (WWF 2001). Additional ecosystems include coastal forest, forest on slopes, fragments of lowland rainforest (below $300 \mathrm{~m}$ ), lowland and montane rainforest, cloud forest, atoll forest and scrub, montane swamp forest, mangrove forest, montane scrub, Pandanus scrub, 


\section{2 / Regina Woodrom Rudrud}

littoral scrub, summit scrub, scrub fernland and grasslands on lava flows and uplands, and sand strand vegetation. Freshwater ecosystems include saltwater and freshwater swamps and marshes, crater marshes, mangrove swamps, mangrove lagoon, streams, crater lakes, streams and other fresh water habitats (Whistler 1980; WWF \& IUCN 1995; Schuster 2001).

Samoa is very rich in marine ecosystems. The volcanic islands are surrounded by fringing reef, while the atolls have steeply sloping sides and Rose Atoll has a lagoon with a sandy bottom and algae. Seagrass beds range from very small and incapable of serving as fish habitat to extensive broad fringing reef and shallow lagoons with seagrasses along most of coast. Fringing reef occur on most islands as well as coralline algal reef flat with abundant corals on vertical surfaces, windward and leeward atoll reef, closed brackish lagoons, and submerged coral banks (UNEP 1998-2006; Wilkinson 2008; SMNRE undated).

Sea turtles are widely distributed throughout the region (Wilkinson 2008). Green and hawksbill turtles are the most commonly occurring and are the only species known to nest in the country (Utzurrum 2002 cited in Fenner et al. 2008). Nesting by both species is reported on Rose atoll, Aleipata Islands (principally Nuutele and Nuulua) and a few beaches on Savaii (Schuster 2001). Additionally hawksbill nesting is reported for Namua and Nuulua beaches on Upolu Island, and Nuutele and Vini beaches on Nuutele Island (Momoemausu et al. 2006). 'There have been occasional records of olive ridley turtles (Lepidochelys olivacea) and a single record of a leatherback (Dermochelys coriaca) from pelagic waters south of Swains Island' (Fenner et al. 2008: 341).

Reports of traditional laws regarding sea turtle consumption in Samoa are contradictory. The earliest report by Turner written in 1861 states, 'and occasionally all, but especially persons of rank, regaled themselves on... turtle... The turtle, too, the best joint, and anything choice, is sure to be laid before the chief' (192, 282 emphasis added). However in his later writing he modifies this report and states, 'The turtle and the mullet were... eaten only by the priest' (Turner 1884: 38). Writing shortly thereafter Stevenson reports turtles belonged to the chief and were used as royal presents for 'the chief of the great powers' (Stevenson 1890; 1983). Additionally, Hiroa provides an account where a Samoan was exiled for 'the theft of a turtle belonging to the tui Manua [high chief or king]' (Hiroa [Buck] 1930: 522).

In reporting the portions of the turtle that were served to the chiefs, Grattan (1948) provides support for consumption only by the chiefs - with the exception of the juice 'that collects in the shell during cooking is highly prized, being dipped out and consumed by the chiefs and orators or divided amongst all the families of the village' (105). Other reports also detail the portions of turtles that were always served to the chiefs, but seem to suggest that there were no restrictions on consuming the rest of the turtle (Finsch 1893 cited in Johannes 1986).

The most comprehensive source is the work of the German anthropologist, Krämer, who reports consumption took place only during special ceremonies and was restricted to the chiefs - with the exception of the hindquarters, which went to the village maid, and the back which went to 'the young men who did the work' (Krämer 1902: 163-164 cited in Hiroa [Buck] 1930: 123). He also includes a footnote that reads, 'a turtle is considered a fish; as a dish for chiefs it is called I' aså... I'as $\bar{a}$ - normally the turtle... taken to the king' (Krämer 1902: 188, 422). Adding to the confusion, Johannes (1986) uses Krämer's word i'asa, but reports after formal presentation to the chief, the orator [talking chief] distributes the meat to the ranking chief's village, but also writes, 'The important parts, the front flippers and rear flippers are reserved for the chiefs... the remaining parts are divided amongst the chiefs and orators [talking chiefs]' (Johannes 1986: 28-29).

\section{Tokelau}

Tokelau consists of three low coral atolls each with a lagoon surrounded by a number of reef-bound islets of varying length. The country covers 10 sq. km of land and a sea area of 290,000 sq. $\mathrm{km}$. The highest point is only $3 \mathrm{~m}$ above $\mathrm{msl}$. The climate is tropical with an average temperature of $28^{\circ} \mathrm{C}$ and average rainfall of 2,500 $\mathrm{mm}$ per year (UNEP 1998-2006). There is no surface fresh water on any of the atolls. The principal terrestrial ecosystems are beach scrub and coconuts, but there are remnants of atoll forest on Tokelau and Long islets in Nukunonu Atoll. There are some tiny brackish pools on two of the atolls and all have atoll reef ecosystems (UNEP 1998-2006; UNEP-WCMC undated).

Three species of sea turtle have been reported in Tokelau - the green, hawksbill and loggerhead. Conservation organisations have reported that all three species nest in the region (UNEPWCMC undated).

Regarding traditional restrictions on sea turtle consumption in Tokelau only two reports have been located (MacGregor 1937; Balazs 1983). Both suggest that sea turtle was divided among all the people, but only within the context of special ceremonies.

\section{Tuvalu}

Of the 10 main islands that make up Tuvalu, five are considered true atolls (Nanumea, Nui, Nukufetau, Nukulaelae and Funafuti) while three are considered table reef islands (Nanumaga, Niutao and Niulakita) (TDOE 2006). Eight of the islands have a surface area less than $10 \mathrm{sq}$. $\mathrm{km}$ and two less than $1 \mathrm{sq}$. $\mathrm{km}$. The country covers $26 \mathrm{sq}$. $\mathrm{km}$ of land and a sea area of $1,300,000 \mathrm{sq}$. $\mathrm{km}$. The highest point is approximately $4 \mathrm{~m}$ above msl (UNEP 1998-2006). Tuvalu is characterised by an immature and infertile soil, unsuitable for subsistence agriculture (TDOE 2007). The climate is tropical with an average temperature of $30^{\circ} \mathrm{C}$ and average rainfall of 2,500 mm per year (Rodgers 1991 cited in WWF 2001; UNEP 1998-2006). Rainwater harvesting is the primary source of water and groundwater is available on all islands (SOPAC 2008; Mongabay 2005).

Though terrestrial resources are poor, Tuvalu has a marine environment rich in coral cover and diversity with a higher ratio of sea to land area than any other nation (Morris \& Mackay 
2008). There are six major marine ecosystems: oceanic, outer reef, lagoonal backreef, lagoon floor, bommies or patch reefs and natural channels between the ocean and lagoon (TDOE 2006). Shallow marine environments are dominated by fringing and patch reefs. Other habitats include small stands of mangroves, lagoons open to the ocean, and landlocked lagoons (Morris \& Mackay 2008).

Turtles are reported to be widely distributed throughout the region and to be protected during nesting season (Morris \& Mackay 2008).

Sea turtle consumption in Tuvalu was restricted to the chiefs (Masso Hadley, Informant 1896 cited in Childress 1998; Zann 1985)

\section{Kingdom of Tonga}

The Kingdom of Tonga is an archipelago of 169 islands. The islands are of volcanic and coral origin, with high and low volcanic as well as raised and low limestone islands. Generally the limestone islands formed from uplifted coral formation though some have limestone overlying a volcanic rock base (PBIF undated). The country covers 715 sq. km of land and a sea area of 700,000 sq. km. The highest point, on the island of Kao, is approximately 1,056 $\mathrm{m}$ above msl (UNEP 1998-2006; PBIF undated). The climate is tropical with an average temperature of $25^{\circ} \mathrm{C}$ and average rainfall of 2,000 mm per year (UNEP 1998-2006). The sources of freshwater for Tonga are rainwater harvesting or extraction from a thin freshwater lens. The exception is 'Eua where freshwater originates from springs in caves high above sea level (UNEP-WCMC undated).

Terrestrial ecosystems in Tonga are abundant. They include forest on lower slopes, tropical moist forest, subtropical rainforest, lowland rainforest, coastal forest and scrub along cliffs, interior rainforests on the higher islands, cloud forest on summits and mangrove forest on many small atoll islands and along lagoon shores of the larger islands. The atolls have ground covers such as Sesuvium, and salt-hardy trees (WWF 2001; PBIF undated). Tropical grasslands, scrub, tropical volcanic crater zone, volcanic crater lakes on Niuafo'ou, Tofua, Kao and Late, swamp, brackish lagoons on Nomuka and 'Uta Vava'u, a freshwater marsh near Tu'anuku on 'Uta Vava'u, and sandy beaches round out the terrestrial environment (Folaumoetu'i 2006).

The archipelago has fringing reef (sometimes poor but in other areas fairly well developed), barrier and submerged reef types, patch reef, salt lagoon reef with coralline algae, wavecut raised reef, windward and leeward atoll reef, detached reef shelf, steep east coast cliffs with terraced pools ringed by coralline algae, seagrass beds, rocky shore with shallow coral patches, and lagoons (UNEP-WCMC undated; Bell et al. 1994; WWF 2001; Palaki 2002).

Four species of sea turtle have been reported in Tonga- the green, hawksbill, olive ridley and leatherback (Dermochelys coriacea). The hawksbill is the most common nesting species while the green turtle is the most commonly caught
(Wilkinson 1979 cited in Bell et al. 1994). Green turtle nesting has been reported on Fetoa, Luamana, Nukufaiva, Nukufalau reef, and Nukulei. Hawksbill nesting has been reported on Nuku. Green and hawksbill nesting have been reported on Kelefesia, Mango, Manoiki, Tonumea. Other nesting reports exist but do not specify the species. These include reports from Felemea, Fonua'one'one, Fouaika, Ha’afeva, Late, Limu, Luahoku, Malinoa, Maninita, Matuku, Taula, Uonuku (Bell et al. 1994; Wilkinson 1979 cited in Bell et al. 1994). Turtles are additionally reported for Fonoifua, Ha'ano, Holopeka, Kito, Koulo, Nomuka (green) O’ua, Pangai, Tungua, and Uiha (Bell et al. 1994; Wilkinson 1979 cited in Bell et al. 1994; Patisepa Folaumoetu'i 2006; Prescott \& Folaumoetu'i 2004).

Sea turtle consumption in Tonga has been reported as restricted to the chiefs, to both chiefs and priests, and as only certain parts going to chiefs and priests (Cook 1821a; Hutton 1874; Thompson 1940a).

\section{Wallis and Futuna}

Wallis and Futuna consists of three main islands each with a surface area of less than 10 sq. km (Ile Uvea, Ile Futuna, Ile Alofi) and 20 low coral or small volcanic islets. The islands are volcanic with low, rolling hills (UNEP 1998-2006; PBIF undated). The country covers $177 \mathrm{sq}$. km of land and a sea area of $300,000 \mathrm{sq} . \mathrm{km}$. The highest point, which lies on the island of Futuna, is $765 \mathrm{~m}$ above $\mathrm{msl}$. The climate is tropical with an average temperature of $27^{\circ} \mathrm{C}$ and average rainfall of $2,750 \mathrm{~mm}$ per year (UNEP 1998-2006). Futuna has many small creeks flowing down the hills in deep gorges and possesses many springs and permanent and intermittent streams. Uvea has several small lakes of volcanic origin as well as a few springs along the coast (UNEP-WCMC undated).

Terrestrial ecosystems in the country include wooded valleys, fernland on ridges, grasslands, montane rainforest, pockets of lowland rainforest, some secondary forest and scrub, and a crater lake. Marine ecosystems include a lagoon rich in algae and barrier reefs. Futuna is surrounded by a narrow fringing reef and there is a small patch of fringing reef on the northwest coast of Alofi (UNEP 1998-2006).

Sea turtle consumption in Wallis and Futuna was restricted to the chiefs (Anon. 1892; Burrows 1936; Burrows 1937; Goldman 1970).

\section{The Polynesian Outliers}

Lying outside the geographic limits of Polynesia are several individual islands, which have been identified by archeologists, anthropologists and linguists as being culturally part of Polynesia that make up what is commonly referred to as the Polynesian Outliers (Bayard 1976). Several of these Outliers had traditional laws pertaining to sea turtle consumption.

From the geographic region of Melanesia, Outliers that have been identified to regulate sea turtle consumption include Rotuma in the Fiji islands where turtle was the son of a god 


\section{4 / Regina Woodrom Rudrud}

and belonged to the spiritual chief and Anuta in the Solomon Islands where turtles were associated with gods and could only be eaten on the 'principal' marae [sacred ceremonial platform] in religious ceremonies and never by members of the god's clan (Gardiner 1898 cited in Craig 1989; Kirch \& Rosendahl 1973; Mageo \& Howard 1996; Parke 2000). Conversely at another outlier in the Solomons, Taumako, turtle consumption was restricted to commoners and was never eaten by chiefs or their families (Firth 1967).

The most contradictory accounts of turtle consumption in the Outliers come from the island Tikopia, also in the Solomons, where some reports state there was only chiefly consumption (or one chiefly lineage), and others report that prior to the 1900s turtle was never eaten by anyone at all (Rivers 1914a; Dillon 1829 both cited in Firth 1936; Firth 1967; Oliver 2002). Finally from Melanesia there is a report from the island of West FutunaAniwa in Vanuatu, and one from Kapingamarangi Atoll in Pohnpei State, Federated States of Micronesia that turtle simply could not be eaten or killed (Emory 1965; Dougherty 1983).

\section{DISCUSSION}

Previous theories regarding the cultures that created sea turtle consumption taboos (versus those that did not) have suggested reliance on an easily depleted natural resource base, life on 'large' islands with more turtle predators, islands with limited shallow marine areas (which would in fact be irrelevant to pelagic sea turtle species), and/or life on 'high' islands with stratified societies led to purely chiefly consumption (Johannes 2002; Allen 2007). The research presented here reveals that the issue is much more complex.

When comparing the geographic and environmental factors of each country, it is clear that none of the standard theoriesenvironmental variability in the resource base, the number and types of natural threats that may additionally deplete those resources, 'high or low' islands - correlate with sea turtle consumption restricted to the elites (Table 1).* Additionally, as expert navigators and sailors, many Polynesians would not be restricted to the resources of their immediate environment as trading within the region (and beyond) was common. Moreover, considering the individual islands, which were singled out during the literature review to have traditional laws concerning sea turtle consumption, we see that environmental variability still does not bear out a causal relationship (Table 2).

What we do see are widespread, similar practices across many environmental types of islands. Such widespread and similar practices suggest an origin in ancestral Polynesian society (Kirch \& Green 2001), possibly before migration took place into this region of the Pacific (Handy 1927; Terrell \& Schechter 2007), which would therefore logically lead to the conclusion that such practices were unrelated to the environments subsequently colonised.

A fundamental question for numerous disciplines is, what drives and directs humans to do what they do (Gragson \& Blount 1999)? For sea turtles in the geographic regions of Polynesia, Melanesia and Micronesia, the crux of this question is in understanding how and why people interact with certain species as beings of great value, elevated through culture into more than just a food source. As more and more Pacific Island nations begin to pressure resource managers for a 'cultural take' of sea turtles (Chaloupka \& Balazs 2007; Kinan \& Drexel 2005; McCoy 1997), and as traditional and historical knowledge vanishes from current generations, the information contained in this paper and the larger project of which it is a part (Woodrom Rudrud in preparation), becomes vital to conservation efforts in the region.

\section{ACKNOWLEDGEMENTS}

I would like to thank Lisa Campbell and Kartik Shanker for inviting me to participate in this special issue of Conservation and Society as well as Jack Frazier and another anonymous reviewer whose comments are probably what made this a readable article. All errors remain mine. I would also like to thank George Balazs whose work on the cultural aspects of sea turtle use in the Pacific first inspired my interest in the subject and Wallace J. Nichols who first inspired in me a love for all things sea turtle at the School for Field Studies in Puerto San Carlos.

\section{Notes}

1. For the purposes of this report the word 'Pacific' refers to the geographic regions of Melanesia, Micronesia and Polynesia.

\section{REFERENCES}

Allen, M.S. 2007. Three millennia of human and sea turtle interactions in remote Oceania. Coral Reefs 26: 959-970.

Anderson, H. 2003. Language contacts in prehistory: Studies in stratigraphy. Philadelphia: John Benjamins Publishing Company.

Anon. 1892. Futuna, or Horne Island and its people. (A compilation of three French works: (1) Nicholet Le R.P. 1890. Vie du Bienheureux PierreLouis-Marie-Chanel. 3 Place Bellicour, Lyon: Emanuel Vitta. (2) Mangeret Le R.P. 1884. Mgr. Bataillon in 2 vols. 90. Rue Bonaparte, Paris: V. Le Coffre. (3) Grezél Le R.P. 1878. Dictionnaire FutunienFrançais. 25 Quai Voltaire, Paris: Maisonneuve et Cie). Journal of the Polynesian Society 1(1): 33-52.

Ariki-tara-are, T. 1919. History and traditions of Rarotonga. Part VII. Journal of the Polynesian Society 28(112): 183-208.

Audran, P.H. 1918. Traditions of and notes on the Paumotu (or Tuamotu) Islands. Part I. Journal of the Polynesian Society 27(105): 26-35.

Balazs, G.H. 1983. Sea turtles and their traditional usages in Tokelau. Atoll Research Bulletin 279: 1-29.

Balazs, G.H. 2010. Green turtles nesting at East Island FFS: Annual trend for 37 seasons. Marine Turtle Research, Pacific Islands Fisheries Science Center, National Marine Fisheries Service.

Balazs, G.H., P. Siu and J.P. Landret. 1995. Ecological aspects of green turtles nesting at Scilly Atoll in French Polynesia. In: Proceedings of the Twelfth Annual Workshop on Sea Turtle Biology and Conservation (eds. Richardson, J.I. and T.H. Richardson). Pp. 7-10. US Department of Commerce, NOAA Technical Memorandum NMFS-SRFSC-361, 274.

Barthel, T. 1923. The eighth land: The Polynesian discovery and settlement of Easter Island. (Translation of Das ache Land). Honolulu: University of Hawaii Press.

Bayard, D. 1976. The cultural relationships of the Polynesian outliers. Otago: University of Otago Prehistoric Anthropology. No. 9.

Beaglehole, E. and P. Beaglehole. 1938. Ethnology of Pukapuka. Bernice P. Bishop Museum Bulletin 150. Honolulu: Bishop Museum. 
Bell, L.A.J., 'U. Fa'anunu and T. Koloa. 1994. Fisheries resources profiles: Kingdom of Tonga. FFA Report 94/05. Available from: http://www.sprep. org/att/IRC/eCOPIES/Countries/Tonga/7.pdf

Bryan, E.H. 1938. Ancient Hawaiian life. Honolulu: Honolulu Advertiser Publishing.

Burrows, E.G. 1936. Ethnology of Futuna. Bernice P. Bishop Museum Bulletin 138. Honolulu: Kraus Reprint Co.

Burrows, E.G. 1937. Ethnology of Uvea (Wallis Island). Bernice P. Bishop Museum Bulletin 145. Honolulu: Kraus Reprint Co.

Chaloupka, M. and G.H. Balazs. 2007. Using Bayesian state-space modeling to assess the recovery and harvest potential of the Hawaiian green sea turtle stock. Ecological Modeling 205(1-2): 93-109.

CIBD (Cook Islands Biodiversity Database). 2007. The Cook Islands Natural Heritage Trust [Webpage]. Available from: http://cookislands. bishopmuseum.org

Cook, J. 1821a. The three voyages of Captain James Cook round the world: Complete in seven volumes. Volume V being the first of the third voyage. London: Longman, Hurst, Rees, Orme, and Brown.

Cook J. 1821b. The three voyages of Captain James Cook round the world: Complete in seven volumes. Volume VII being the third of the third voyage. London: Longman, Hurst, Rees, Orme, and Brown.

Craig, P., D. Parker, R. Brainard, M. Rice and G. Balazs. 2004. Migrations of green turtles in the central South Pacific. Biological Conservation 116: $433-438$

Craig, R.D. 1989. Dictionary of Polynesian mythology. California: Greenwood Publishing Group.

Crocombe, R.G. 1961. Land tenure in the Cook Islands. Ph.D. Thesis. Australian National University, Australia. Canberra: Australian National University Press.

Danielsson, B. 1954. Raroian culture. Atoll Research Bulletin 32: 1-109.

Dillon, P. 1829. Narrative and successful result of a voyage in the south seas, performed by order of the Government of British India, to ascertain the actual fate of La Perouse's Expedition, interspersed with accounts of the religion, manners, customs, and cannibal practices of the South Sea Islanders. In two volumes. Volume I. London: Hurst, Chance and Co.

Dougherty, J.W. 1983. West Futuna-Aniwa: An introduction to a Polynesian outlier language. California: University of California Press.

Ellis, W. 1827. Narrative of a tour through Hawaii, or Owhyhee; with observations on the natural history of the Sandwhich Islands, and remarks on the manners, customs, traditions, history, and language of their inhabitants. $2^{\text {nd }}$ edition. London: H. Fisher, Son, and P. Jackson.

Ellis, W. 1831. Polynesian researches, during a residence of nearly eight years in the Society and Sandwhich Islands. $2^{\text {nd }}$ edition, enlarged and improved. Volume I. London: Fisher, Son, \& Jackson.

Emory, K.P. 1975. Material culture of the Tuamotu Archipelago. Pacific Anthropological Records 22. Honolulu: Bishop Museum Press.

Emory, K.P. 1947. Tuamotuan religious structures and ceremonies. Bernice P. Bishop Museum Bulletin 191. New York: Kraus Reprint Co.

Emory, K.P. 1965. Kapingamarangi, social and religious life of a Polynesian Atoll. Bernice P. Bishop Museum Bulletin 228. Honolulu: Bishop Museum Press. 357 pp.

Etkin, N. 2008. Food, health and society. In author's personal files. Available upon request. College of Social Sciences, University of Hawai'i at Manoa.

EVI (Environmental Vulnerability Index - Country Profiles). 2010. Pacific Environment Information Network [PEIN] Country Profiles Directory [webpage]. Secretariat of the Pacific Regional Environmental Programme [last updated 10 March 2010].

Fenner, D., M. Speicher and S. Gulick (eds). 2008. The state of coral reef ecosystems of American Samoa. Available from: http://www.sprep.org/ att/IRC/eCOPIES/Countries/American_Samoa/16.pdf

Ferdon, E.N. 1981. Early Tahiti as the explorers saw it: 1767-1797. Tucson: University of Arizona Press.
Finsch, O. 1893. Ethnologische erfahrungen und belegstücke aus der Südsee: Beschreibender katalog einer sammlung in K.K. Naturhistorischen Hofmuseum in Wien. Vienna: Alfred Hölder.

Firth, R.W. 1936. We, the Tikopia: A sociological study of kinship in primitive Polynesia. London: George Allen and Unwin, Ltd. New Haven: HRAF, 1995. Computer File Doc. Number 2.

Firth, R.W. 1967. Sea creatures and spirits in Tikopia belief. In: Polynesian culture history: essays in honor of Kenneth P. Emory (eds. Highland, G.A., R.W. Force, A. Howard, M. Kelly and Y.H. Sinoto). Pp. 539-564. Honolulu: Bishop Museum Press.

Folaumoetu'i, P. 2006. National Biodiversity Strategy \& Action Plan. Tonga Department of Environment. Available from: http://www.sprep.org/att/ IRC/eCOPIES/Countries/Tonga/9.pdf

Fosberg, F.R. 1992. Vegetation of the Society Islands. Pacific Science 46: 232-250.

Gill, W.W. 1885. Jottings from the Pacific. London: The Religious Tract Society.

Goldman, I. 1970. Ancient Polynesian Society. Chicago: University of Chicago Press.

Government of Niue. 2001. Niue National Biodiversity Strategy and Action Plan. Available from: http://www.sprep.org/att/IRC/eCOPIES/ Countries/Niue/4.pdf

Grattan, F.J.H. 1948. An introduction to Samoan custom. Papakura: Mcmillan.

Gulko, D. 1998. Hawaiian coral reef ecology. Honolulu: Mutual Publishing.

Handy, E.S.C and M.K. Pukui. 1953. The Polynesian family system in Ka'u, Hawaii, VII. Traditional manners and customs and the social order. Journal of the Polynesian Society 62(4): 295-341.

Handy, E.S.C. 1923. The native culture in the Marquesas. Bernice P. Bishop Museum Bulletin 9. Honolulu: Bishop Museum Press.

Handy, E.S.C. 1927. Polynesian religion. Honolulu: Bishop Museum Press.

Handy, E.S.C. and E.G. Handy (with the collaboration of M.K. Pukui). 1972. Native planters in old Hawaii: Their life, lore, and environment. Bernice P. Bishop Museum Bulletin 233. Honolulu: Bishop Museum Press. Human Relations Area Files, 2003. Computer File Doc. Number: 5.

Hiroa, T.R. (P.H. Buck). 1932. Ethnology of Tongareva. Bernice P. Bishop Museum Bulletin 92. New York: Kraus Reprint Co.

Hiroa, T.R. (P.H. Buck). 1938a. Ethnology of Mangareva. Bernice P. Bishop Museum Bulletin 157. New York: Kraus Reprint Co.

Hiroa, T.R. (P.H. Buck). 1938b. Vikings of the sunrise. New Zealand and New York: Frederick A. Stokes Company. 335pp.

Hiroa, T.R. (P.H. Buck). 1930. Samoan material culture. Honolulu: Bishop Museum Press.

Hutton, J. 1874. Missionary life in the southern seas. London: Henry S. King \& Co.

Johannes, R.E. 1986. A review of information on the subsistence use of green and hawksbill sea turtles on islands under United States jurisdiction in the Western Pacific Ocean. US Department of Commerce National Oceanographic and Atmospheric Administration National Marine Fisheries Service Administrative Report SWR-86-2. 41: 28-29.

Johannes, R.E. 2002. Did indigenous conservation ethics exist? SPC Traditional Marine Resource Management and Knowledge Information Bulletin 14: 3-7.

Kalakaua, D. 1888. The legends and myths of Hawaii. New York: C.L. Webster and Co.

Kinan, I. and P. Drexel. 2005. Turtle conservation and fisheries development in the Pacific Islands: Different perspectives create conflicts between developed and developing economies. Sea turtles: Flagship species for conservation and fishery management. Maritime Studies 3(2) and 4(1).

Kirch, P.V. and P. Rosendahl. 1973. Archaeological investigations of Anuta. Pacific Anthropological Records 21: 25-108.

Kirch, P.V. and R.C. Green. 2001. Hawaiki, ancestral Polynesia: An essay in historical anthropology. Cambridge: Cambridge University Press. 


\section{6 / Regina Woodrom Rudrud}

Krämer, A. 1902. Die Samoa-Inseln. Volume 1. Stuttgart.

Krämer, A. 1902. The Samoa Islands: An outline of a monograph with particular consideration of German Samoa. Volume I. [Translated by Verhaaren, Theodore in 1994]. Honolulu: University of Hawaii Press.

Lane, J. 1994. Niue-State of the Environment Report 1993. South Pacific Regional Environment Programme, Apia, Samoa.

Large, J.T. 1903 (translator). The Aitutaki version of the story of Iro. Journal of the Polynesian Society 12(3): 133-144.

Linnekin, J. 1990. Sacred queens and women of consequence: Rank, gender, and colonialism in the Hawaiian Islands. Ann Arbor: University of Michigan Press. New Haven: HRAF, 2003. Computer File Doc. Number 13.

Loeb, E.M. 1926. History and traditions of Niue. Bernice P. Bishop Museum Bulletin 32. New York: Kraus Reprint Co.

Lovell, E.R. and A. Palaki. 2002. National coral reef status report Tonga. Available from: http://www.sprep.org/att/IRC/eCOPIES/Countries/ Tonga/5.pdf

Macgregor, G. 1937. Ethnology of Tokelau Islands. Bernice P. Bishop Museum Bulletin 146. Honolulu: Bishop Museum Press.

Mageo, J.M and A. Howard. 1996. Spirits in culture, history, and mind. London: Routledge.

Malo, D. 1951. Hawaiian antiquities: Mo'olelo Hawaii. Honolulu: Bishop Museum Press.

McCalester USA. Undated. Easter Island [Webpage]. Available from: http:// mcalester.us/index.php?option=com_awiki\&view=mediawiki\&Itemid $=1994 \&$ article $=$ Easter Island

McCoy, M.A. 1997. The traditional and ceremonial use of the Green sea turtle (Chelonia mydas) in the Northern Mariana Islands: With recommendations for its use in cultural events and education. A report prepared for the Western Pacific Regional Fishery Management Council \& University of Hawai 'i, Sea Grant College Program.

Meller, N. 1985. Indigenous ocean rights in Hawaii. Sea Grant Marine Policy and Law Report, University of Hawaii, December 1985.

Momoemausu, M., J. Ward, M. Iakopo, P. Ifopo and F. Sio. 2006. Report on the Hawksbill Turtle Nesting Survey 2005-2006. Samoa: Division of Environment and Conservation, Ministry of Natural Resources and Environment. Unpublished report.

Mongabay. 2005. Mongabay rainforest profiles. Available from: http:// rainforests.mongabay.com/deforestation/2000/Tuvalu.htm

Montgomery, J. (compiler). 1841. Voyages and travels round the world by the Rev. Daniel Tyerman and George Bennet, Esq. deputed from the London Missionary Society to visit their various stations in the South Sea Islands, Australia, China, India, Madagascar, and South Africa between the years 1821 and 1820. $2^{\text {nd }}$ edition, corrected. London: John Snow.

Montiton, A. 1874. Les Paumotus. Les Missions Catholiques 6 (Jan-Dec).

Morris, C. and K. Mackay (eds.). 2008. Status of the coral reefs in the South West Pacific: Fiji, New Caledonia, Samoa, Solomon Islands, Tuvalu and Vanuatu. Available from: http://www.sprep.org/att/IRC/eCOPIES/ Pacific_Region/376.pdf

MRCI (Ministry of Marine Resources Government of the Cook Islands). Undated. Basic Information on the Marine Resources of the Cook Islands [Webpage]. Pacific Environment Information Network [PEIN] Country Profiles Directory, Secretariat of the Pacific Regional Environmental Programme [last updated 10 March 2010]. Available from: http://www. sprep.org/publication/PEIN_Country_Profiles.asp\#Profiles

Nemaia, F.A. (compiler). 2004. National Action Plan Addressing Land Degradation and Drought. Available from: http://www.sprep.org/att/ IRC/eCOPIES/Countries/Niue/34.pdf

NMFS (National Marine Fisheries Service). 1998. Contract between the National Marine Fisheries Service and the Marine Option Program (MOP), University of Hawaii at Manoa, Contract duration: March 1, 1998 to September 30, 1998.

Oliver, D.L. 2002. Polynesian in early historic times. Honolulu: Bess Press.
Pakoti, J. 1895. Te autara ia Aitutaki: Tona katiri anga ia. Ko te autara teia ia $R u$ (The first inhabitants of Aitutaki: The history Of Ru) [Translated by Henry Nicholas]. Journal of the Polynesian Society 4(1): 59-70.

Parke, A.L. 2000. Rotuma: The changing nature of customary authorities. Journal of Pacific History 35(1): 101-108.

Parsons, J.J. 1962. The green turtle and man. Gainesville: University of Florida Press.

PBIF (Pacific Biodiversity Information Forum Country Data). Undated. Pacific Environment Information Network [PEIN] Country Profiles Directory [webpage]. Secretariat of the Pacific Regional Environmental Programme [last updated 10 March 2010].

PEIN (Pacific Environment Information Network). 2010. Country Profiles Directory [webpage]. Secretariat of the Pacific Regional Environmental Programme [last updated 10 March 2010].

Per. com. D. Heacock DLNR Kauai. 2009. Conversation while retrieving frozen stranded sea turtles from the DLNR freezer on the island of Kauai.

Per. com. G. Balazs NOAA Fisheries. 2008. Verbal instructions regarding this author's contract to conduct nesting surveys on the Island of Oahu.

Prescott, N. and P.S. Folaumoetu'i. 2004. Tonga Biodiversity Stock Taking. Available from: http://www.sprep.org/att/IRC/eCOPIES/Countries/ Tonga/10.pdf

Pulea, M. 1992. Legislative Review of Environmental Law Cook Islands. South Pacific Regional Environment Programme. Regional Technical Assistance Project 11 Title III (Series). Available from: http://www.sprep. org/att/IRC/eCOPIES/Countries/Cook_Islands/10.pdf

PWF (Pacific Whale Foundation). Undated. Sea Turtles: A Hawai 'i Wildlife Guide. http://www.pacificwhale.org.

Rivers, W.H.R. 1914a. Chapter 12. In: The History of Melanesian Society (ed. Rivers, W.H.R.). Volume 1. Cambridge, England: Cambridge University Press. New Haven: HRAF, 1995. Computer File Doc. Number 16.

Rodgers, K.A. 1991. A brief history of Tuvalu's natural history. South Pacific Journal of Natural Science 11: 1-14.

Rolett, B.V. 1986. Turtles, priests, and the afterworld: A study in the iconographic interpretation of Polynesian petroglyphs. In: Island Societies: Archaeological approaches to evolution and transformation (ed. Kirch, P.V.). Pp. 78-87. New York: Cambridge University Press.

Schuster, C. (ed). 2001. Samoa's Biodiversity Strategy and Action Plan: Keep the Remainder of the Basket. Available from: http://www.sprep.org/att/ IRC/eCOPIES/Countries/Samoa/8.pdf

Sharp, A. 1963. Ancient voyagers in Polynesia. Los Angeles: University of California Press.

Smith S.P. 1903. Arai-te-tonga, the ancient marae at Rarotonga. Journal of the Polynesian Society 12(4): 218-220.

Smith, S.P. 1889. Tongarewa, or Penrhyn Island, and its people. [Read before the Auckland Institute, 14th October, 1889.] Transactions and Proceedings of the Royal Society of New Zealand 22.

SMNRE (Samoa Ministry of Natural Resources \& Environment). Undated. Samoa's Biodiversity [Webpage]. Available from: http://www.mnre.gov. ws/biodiversity/default.cfm

SOPAC (Pacific Islands Applied Geoscience Commission). 2008. Integrated Water Resource Management Profiles [Webpage]. [last updated $21 \mathrm{Feb}$ 2008]. Available from: http://www.sopac.org/homepage

Stevenson, R.L. 1890. In the south seas. London: Cassel.

Stone, C.P. and J.M. Scott (eds.) 1985. Hawaii's terrestrial ecosystems: Preservation and management. Proceedings of a symposium held June 5-6, 1984 at Hawaii Volcanoes National Park. Cooperative National Park Resources Studies Unit, University of Hawaii. Honolulu. 584 pp.

Terrell, J.E. and E.M. Schechter. 2007. Deciphering the Lapita code: The Aitape ceramic sequence and late survival of the 'Lapita Face'. Cambridge Archaeological Journal 17(1): 59-85.

TGOH (The Geography of Hawaii). 2009. [Webpage]. Last updated: September 24, 2009. Available from: http://www.netstate.com/states/ geography/hi_geography.htm 
Thompson, L. 1940a. Southern Lau, Fiji: An ethnography. Bernice P. Bishop Museum Bulletin 162. New York:: Kraus Reprint Co.

Turner, G. 1861. Nineteen years in Polynesia: Missionary life, travels, and researches in the Islands of the Pacific. London: J. Snow.

Turner, G. 1884. Samoa a hundred years and long before: Together with notes on the cults and customs of twenty-three other islands in the Pacific. London: Macmillan.

Tuvalu Department of Environment (TDOE). 2006. National Action Plan to Combat Land Degradation and Drought. Available from: http://www. sprep.org/att/IRC/eCOPIES/Countries/Tuvalu/51.pdf

Tuvalu Department of Environment (TDOE). 2007. Tuvalu's National Adaptation Programme of Action Under the auspices of the United Nations Framework Convention on Climate Change. Available from: http://www.sprep.org/att/IRC/eCOPIES/Countries/Tuvalu/7.pdf

UNEP (United Nations Environment Programme). 1998-2006. Access to information on islands and small island developing States (SIDS) especially from within the United Nations system [Webpage]. [last updated 22 Jun 2006]. Available from: http://islands.unep.ch/

UNEP-WCMC (United Nations Environment Program and World Conservation Monitoring Center). Undated. Wetlands in Oceania country profiles and wetlands information. Available from: http://www. unep-wcmc.org/sites/wetlands/pyf.htm

Utzurrum, R.C.B. 2002. Sea turtle conservation in American Samoa. In: Proceedings of the western Pacific sea turtle cooperative research and management workshop (ed. Kinan, I.). Honolulu: Western Pacific Regional Fishery Management Council. Pp. 33-36.

Whistler, W.A. 1980. The vegetation of eastern Samoa. Allertonia 2: 45-158.

Wilkinson, C. (2008). Status of coral reefs of the world: 2008. Townsville: Global Coral Reef Monitoring Network and Reef and Rainforest
Research Centre.

Wilkinson, W.A. (1979). Fisheries Annual Report. Kingdom of Tonga.

Williams, J. 1837. A narrative of missionary enterprises in the South Sea Islands: With remarks upon the natural history of the islands, origin, languages, traditions, and usages of the inhabitants. London: J. Snow.

Williamson, R.W. 1933. Religious and cosmic beliefs of central Polynesia. Cambridge: University Press.

Wilson, J. 1799. A missionary voyage to the Southern Pacific Ocean, performed in the years 1796, 1797, 1798 in the Ship Duff commanded by Capt. James Wilson. London: T. Chapman.

Woodrom Luna, R. 2003. The merging of archaeological evidence and marine turtle ecology: A case study approach to the importance of including archaeological data in marine science. SPC Traditional Marine Resource Management and Knowledge Information Bulletin 15: 26-30.

Woodrom Rudrud, R., J. Walsh Kroeker, H. Young Leslie and S. Finney. 2007. Sea turtles wars: Culture, war and sea turtles in the Republic of the Marshall Islands. SPC Traditional Marine Resource Management and Knowledge Information Bulletin 21: 3-29.

WWF (World Wildlife Fund for Nature). 2001. Ecoregions: Oceania. Available from: http://www.worldwildlife.org/wildworld/profiles/ terrestrial_oc.html

WWF and IUCN (World Wild Life Fund and International Union for the Conservation of Nature). 1995. Centres of plant diversity. A guide and strategy for their conservation. Volume 2. Asia, Australasia and the Pacific. Cambridge: IUCN Publication Unit.

y Varela, J.A. 1913. Narrative of a voyage performed to the Island of Amat, otherwise by name Otahiti... in the years 1774 and 1775. In: The quest and occupation of Tahiti by emissaries of Spain during the years 1772-1776 (ed. Corney, B.G.). Mexico: The Hakluyt Society. 